\title{
Mole Cricket Nematode, Steinernema scapterisci Nguyen \& Smart (Nematoda: Rhabditida: Steinernematidae) ${ }^{1}$
}

K. B. Nguyen ${ }^{2}$

\section{Introduction}

The most important insect pests of turf and pastures in Florida are mole crickets. And their damage is not restricted to grasses. Their feeding and tunneling also destroy seedlings of vegetables, ornamentals, and tobacco. Insecticides commonly applied to control mole crickets in lawns, golf courses, and seed beds are expensive and not always effective. In pastures, there is no control that is economically feasible; yet without control, stands of pasture grasses are frequently so reduced as to require replanting.

In 1985, a steinernematid nematode, parasite of mole crickets, was brought from Uruguay to Florida. That nematode, which was described as a new species, Steinernema scapterisci (Nguyen and Smart, 1990), appears to be a major factor limiting populations of mole crickets in South America.

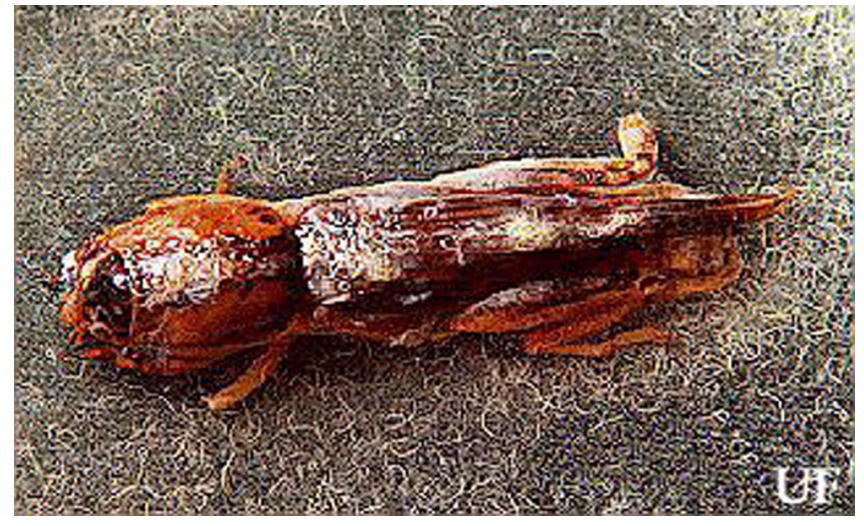

Figure 1. Mole cricket nematodes, Steinernema scapterisci Nguyen \& Smart, emerging from a mole cricket. Credits: K. Nguyen, University of Florida

\section{Description}

\section{Male, First-Generation}

A first generation male is much smaller than a first generation female, but anatomically the two are similar anteriorly. The body is usually plump and the head is rounded continuous with body. Lips not seen but six labial papillae are prominent, and four cephalic papillae are well developed, much larger than cephalic papillae. Esophagus steinernematoid,

1. This document is EENY-092, one of a series of Featured Creatures from the Entomology and Nematology Department, Florida Cooperative Extension Service, Institute of Food and Agricultural Sciences, University of Florida. Published: June 1999. Revised: August 1999. Reviewed: May 2003. This document is also available on Featured Creatures Website at http://creatures.ifas.ufl.edu. Please visit the EDIS Website at http://edis.ifas.ufl.edu. Additional information on these organisms, including many color photographs, is available at the Entomology and Nematology Department WWW site at http://entnemdept.ifas.ufl.edu/.

2. K. B. Nguyen, Entomology and Nematology Department, Institute of Food and Agricultural Sciences, University of Florida, Gainesville, FL 32611.

The Institute of Food and Agricultural Sciences (IFAS) is an Equal Employment Opportunity - Affirmative Action Employer authorized to provide research, educational information and other services only to individuals and institutions that function without regard to race, creed, color, religion, age, disability, sex, sexual orientation, marital status, national origin, political opinions or affiliations. For information on obtaining other extension publications, contact your county Cooperative Extension Service office. Florida Cooperative Extension Service / Institute of Food and Agricultural Sciences / University of Florida / Larry R. Arrington, Interim Dean 
procorpus cylindrical, metacorpus slightly swollen, isthmus distinct, basal bulb swollen with small valve. Nerve ring located in isthmus region of esophagus but position variable. Excretory pore located anterior to mid-esophagus. Excretory duct not forming elliptically-shaped structure present in females. Posterior part of body curved ventrally. Body assumes a spiral shape when killed by minimal heat. Gonad single, testis reflexed. Spicules averaging 83 micrometers long, dark brown in color, paired, uniformly curved, with head large and somewhat angular. Angle formed by shaft and blade of spicules averages 110 degrees (range 100-120). Shaft of spicules long when compared to those of other species of the genus, and appears to be encased in a sheath; blade tapers smoothly to end with posterior portion thinner than that for other species of Steinernema. A small aperture can be seen on ventral side close to tip of the blade. Each spicule has two internal ribs with variable termination point proximally. Gubernaculum boat-shaped, with anterior part thin, long and ventrally-curved. Spicules glide along gubernaculum in two grooves separated by a needle-shaped cuneus. Cloaca on a raised area bearing an anterior flap, seen easily when the spicules are protracted or retracted. Eleven or 12 pairs and one single genital papillae observed. One special pair located at the edge of cloaca. Tail with a mucron. No phasmid observed.

\section{Male, Second Generation}

A second generation male is similar morphologically to that of the first generation except that it is about two-thirds as long and one-half as wide and the spicules have an elongate head.

\section{Female, First Generation}

Anteriorly, the female is similar to male but much larger. Lateral fields and phasmids not observed. Six labial papillae and four cephalic papillae present. Stoma with prominent cheilorhabdions unusually thickened, appearing as a circular or hexagonal ring in face view. Esophagus typical of family. Esophago-intestinal valve large. Excretory pore located anteriorly to mid-metacorpus.

Excretory duct unusually prominent forming an elliptically-shaped structure seemingly with a hole at

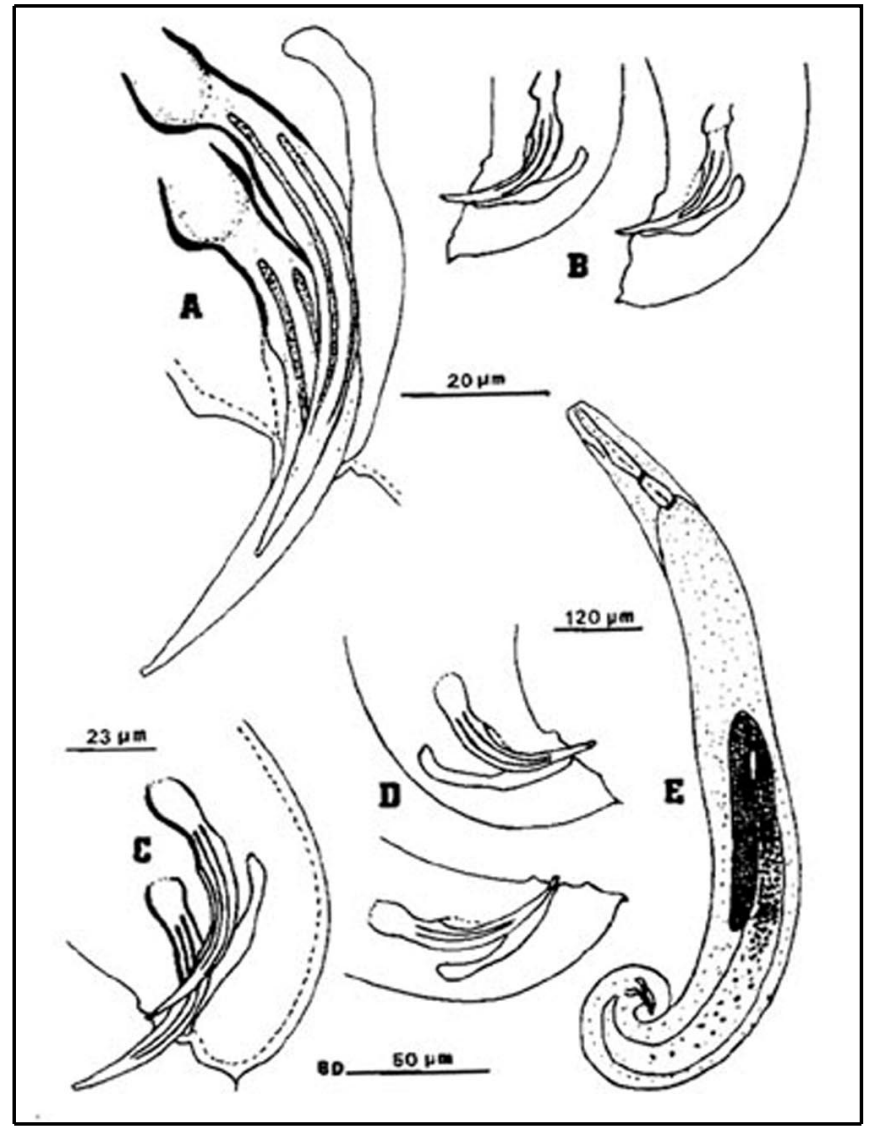

Figure 2. Males of the mole cricket nematode, Steinernema scapterisci Nguyen \& Smart n. sp. A) Spicules of the first-generation male showing angular head, ribs, and gubernaculum with anterior end bent upward. B) Variation in the tail shape of the first-generation males. C) Tail of the second-generation male showing elongae spicule head. D) Variation in tail shape of second-generation males. E) Entire body of the first-generation male. Credits: K. Nguyen, University of Florida

the center. Gonads didelphic, amphidelphic, reflexed. Vulva appears as a transverse slit with a prominent double-flapped epiptygma. Tail length shorter than anal body width, with a mucron at end.

\section{Females, Second Generation}

Second generation female similar morphologically to that of the first generation with the following exceptions: about one-half as long and two-thirds as wide, valve in basal bulb of esophagus more prominent, elliptically-shaped structure less prominent, tail, which tapers to a point bearing a mucron, longer than body width at anus. 

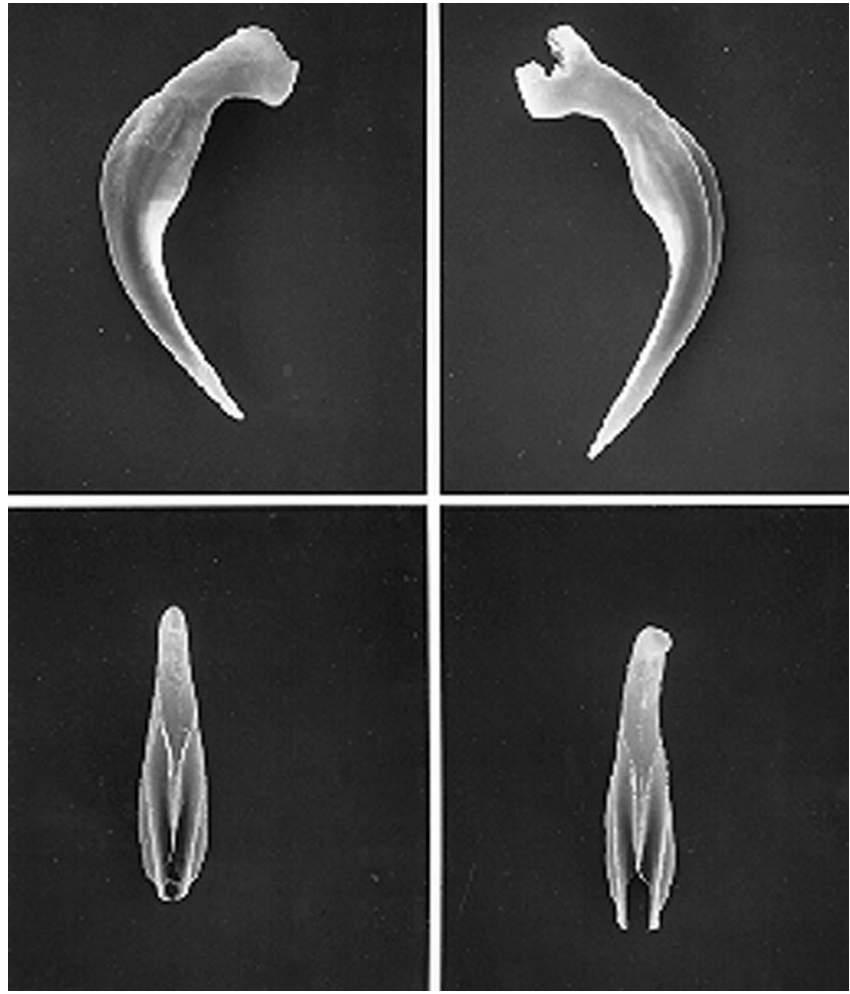

Figure 3. Spicules (top) and gubernaculum (bottom) of the mole cricket nematode, Steinernema scapterisci Nguyen \& Smart. Credits: K. Nguyen, University of Florida

\section{Infective Juveniles (Third Stage)}

The infective stage, when newly formed, is always enclosed in the cuticle of the second-stage juvenile as a sheath. However, the sheath is lost rather easily, even in storage, and thus may not always be present. Body thin, head with a labial raising disc; lip region not offset, oral aperture not observed; six labial, four cephalic papillae and an elevated oral disc prominent. Esophagus degenerate and thus not seen clearly, but its basal bulb is elongate and has a valve. Lateral field with six incisures. Tail tapers gradually dorsally but abruptly ventrally.

\section{Biology and Life Cycle}

The life cycle of Steinernema scapterisci Nguyen and Smart,, 1990 consists of an egg stage, four juvenile stages, and an adult stage (male and female). The cycle from IJ (third stage infective juveniles) to IJ may proceed by one of two routes. If the nutrient supply is sufficient and the population is not overcrowded, the IJ develop to adult males and females of the first generation. Most eggs from these

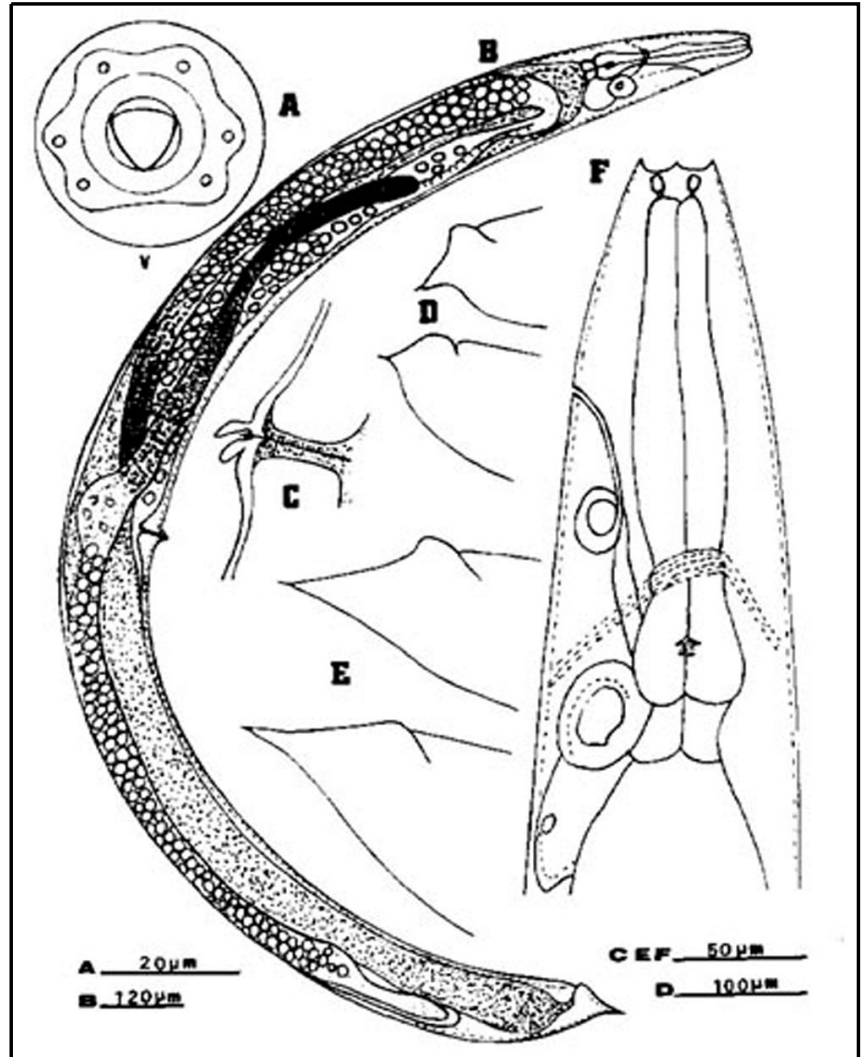

Figure 4. Females of the mole cricket nematode, Steinernema scapterisci Nguyen \& Smart n. sp. A) Diagrammatic face view of the first-generation female showing unevenly distributed papillae. B) Entire body of second-generation females. C) Double-flapped epiptygma on vulva of the first-generation females. D) Varation in tails of the first-generation females. E) Varation in tails of second-generation females. F) Anterior region of the first-generation female showing large cheilorhabdions, esophagus, nerve ring, excretory pore and duct, and elliptically shaped structure and gland cell associated with the excretory system. Credits: K. Nguyen, University of Florida

adult females hatch and the juveniles develop through each life stage to become adult males and females of the second generation. Eggs produced by these females develop to IJ. This cycle takes eight to 10 days (long cycle) at $24 \mathrm{C}$. If the nutrient supply is insufficient or if overcrowded, the IJ develop to adult males and females of the first generation, and eggs produced by the females develop directly to IJ. This cycle takes six to seven days (short cycle). The nematode is less tolerant of lower temperatures and more tolerant of higher temperatures than are other species of the genus. The sex ratio is influenced by temperature. At 15 and $24 \mathrm{C}$, females constituted 54 percent and 60 percent of the population, 

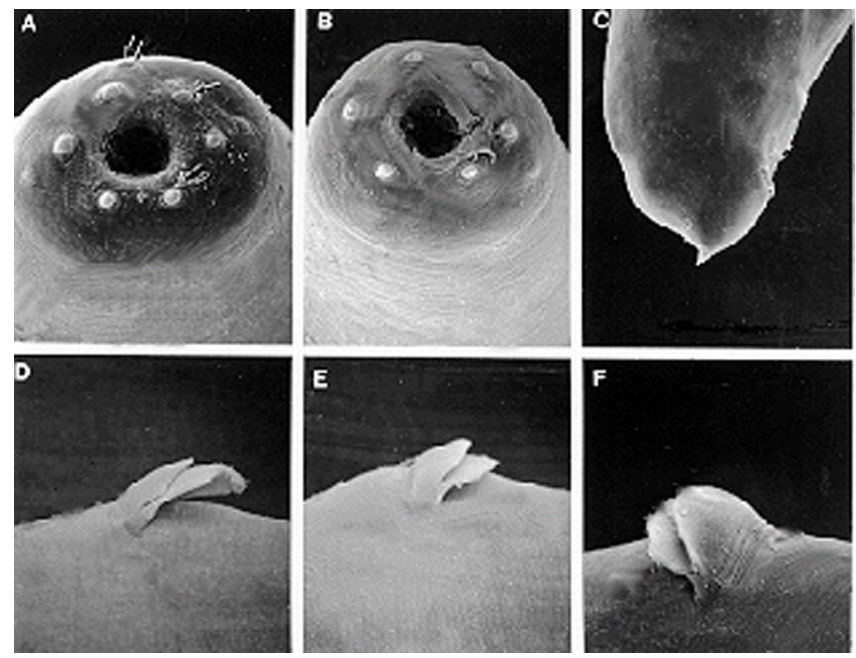

Figure 5. A, B - face views of first generation females; C female tail; D, E, F - double flapped epiptygma; of the mole cricket nematode, Steinernema scapterisci Nguyen \&

Smart. Credits: K. Nguyen, University of Flor

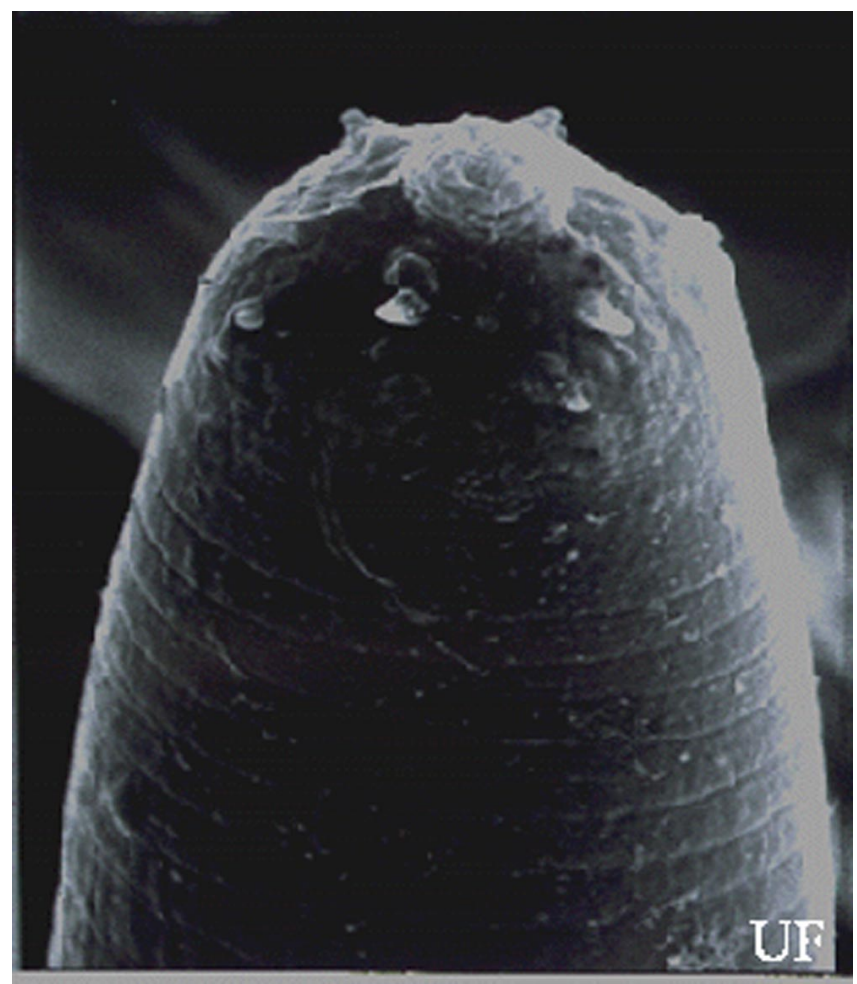

Figure 6. Infective juvenile of the mole cricket nematode, Steinernema scapterisci Nguyen \& Smart, with the head showing labial raising disc. Credits: K. Nguyen, University of Flor

respectively, but at $30 \mathrm{C}$ females constituted 47 percent of the population.

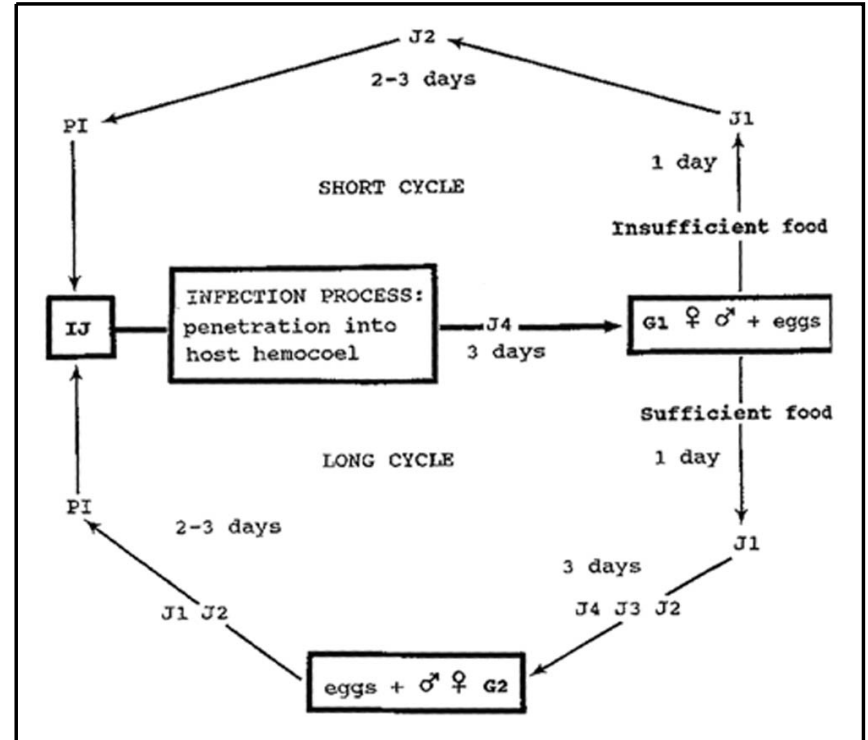

Figure 7. Diagram of the life cycle of Steinernema scapterisci. G1 = first-generation adults, G2 = second-generation adults, $\mathrm{J} 1$ = first-stage juvenile, $\mathrm{J} 2$ = second-stage juvenile that may be the preinfective or non-preinfective stage, $\mathrm{J} 3$ = third stage noninfective juvenile, $\mathrm{PI}=$ preinfective stage, $\mathrm{IJ}=$ third-stage infective juvenile, J4 = fourth-stage juvenile.

\section{Distribution and Hosts}

S. scapterisci was originally found in Argentina, Brazil and Uruguay and recently in the United States. It was reported to infect and kill insects in the order Orthoptera: mole crickets of the genera Scapteriscus and Neocurtilla; house cricket, Acheta domesticus; field crickets, Gryllus sp.; eastern lubber grasshopper, Romalea guttata. Insects in the orders Coleoptera, Lepidoptera, Hymenoptera are poor hosts or non-hosts.

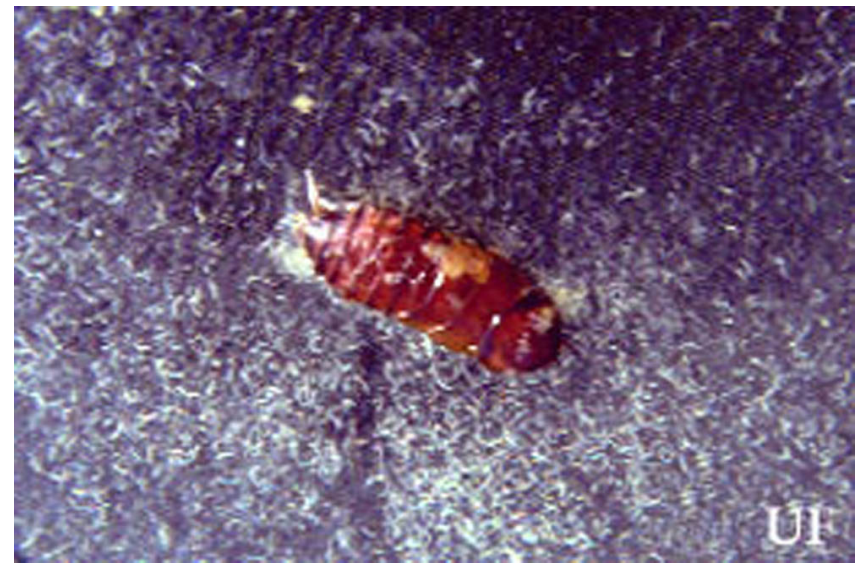

Figure 8. Mole cricket nematodes, Steinernema scapterisci Nguyen \& Smart, emerging from a cockroach nymph. Credits: K. Nguyen, University of Florida 


\section{Release and Dispersal}

The research to use entomopathogenic nematodes to control mole crickets began in 1983 by conducting a survey in attempts to find mole crickets infected with steinernematid or heterorhabditid nematodes. About two thousand mole crickets from Alachua County, Florida, and a few from other counties in the state, were collected and held until they died. Three to five days after they died the cadavers were dissected and examined for steinernematid or heterorhabditid nematodes. No heterorhabditids were found and only four were infected with steinernematids. One of those was infected with $S$. glaseri, and three were infected with $S$. carpocapsae. Progeny of these nematodes were used in laboratory experiments to infect other mole crickets. Neither of the species infected mole crickets well, or reproduced well in those that became infected.

The nematode was not found in Florida before the release in 1985. When the nematode was applied to small plots in 1985 in Alachua County, Florida, a maximum of 40 percent infection of those mole crickets was collected in pitfall traps during a 24-hour collection period immediately after application. These plots were sampled monthly for five years and, on average about 10 percent of the mole crickets trapped were infected. That 10 percent, coupled with the higher initial infection, was sufficient to reduce populations of nymphal mole crickets collected in pitfall traps by about 85 percent after one year and 95 percent or more there after. The nematode persisted in the plots for at least the duration of our five year sampling period. The effectiveness of the nematode is due in part to the fact that the mole crickets have only one generation per year in North Florida and the nematode, theoretically, could produce a new generation every 10 days for approximately eight months of the year.

Three years after the nematode was released, a few mole crickets collected in a farm 10 miles from the nearest release site were found infected with the nematode. By the fifth year, 25 to 65 percent of the mole crickets collected at this farm were infected (Smart, et al. 1990).
Since 1985 Steinernema scapterisci has been detected in mole crickets collected from several other sites in Alachua county, spread from our original release sites, undoubtedly by mole crickets during the flight period after they became infected but were still capable of flight. Up to November, 1998, about 10 to 30 percent of mole crickets collected in Alachua county, Florida have been infected with $S$. scapterisci.

In 1990 and 1991, the nematode was released in pastures in six different counties and on nearly 30 golf courses in Florida. It has become established and has reduced populations of mole crickets in all of the pastures.

How to obtain S. scalpterisci nematodes

\section{Bionomics and Host Parasite Relationships}

The nematode can survive and still be infective in the absence of hosts for at least 10 weeks in moist soil (Nguyen \& Smart, 1990a). When infective juveniles (IJ) of Steinernema scapterisci were released on the soil surface in the field and in the laboratory, they moved downward through the soil at least $10 \mathrm{~cm}$ in five days, infected and killed mole crickets (Nguyen \& Smart, 1990b). When IJ were placed at the center of a 16-cm soil column, they moved in both directions with three times more moving downward than upward. In the field, nematode-infected mole crickets in the early stage of infection spread the nematode during their flight (Smart, et al. 1991). Consequently, the nematode can be dispersed from inoculative field releases on golf courses and pastures (Parkman et al. 1993a, 1993b). The IJ enter the host through the mouth or spiracles (Nguyen \& Smart, 1992). They develop in the host in the same way as other species of Steinernema.

\section{Bacterial Associates}

Bacteria from Steinernema scapterisci cultured in vivo, in vitro and collected from fields were isolated and identified (Anguillera et al. 1993a). Many bacteria were associated with this nematode: Ochrobactrum anthropi, Paracoccus denitrificans, Xanthomonas maltophilia, Xenorhabdus bovienii, X. nematophilus, Xenorhabdus spp. These bacteria and 
three others, Pseudomonas fluorescens, $P$. aureofacians, and Escherichia coli were used for in vitro culture of this nematode. The nematode developed normally and produced IJ with all studied bacteria (Anguillera et al. 1993b). This fact shows that the nematode can feed on different bacteria, consequently, the nematode survives very well under field conditions.

\section{Biocontrol Capability}

Steinernema scapterisci is specific to mole crickets. The nematode was successfully introduced by inoculative applications in golf courses and pastures (Parkman et al. 1993, 1994) in Florida Since 1993 this nematode has been commercialized in Florida to control mole crickets in golf courses and pastures.

\section{Selected References}

Anguillera, M.M., and G.C. Smart, Jr. (1992). Bacterial symbionts of Steinernema scapterisci. Journal of Invertebrate Pathology, 62:68-72.

Anguillera, M.M., and G.C. Smart, Jr. (1992). Development, reproduction, and pathogenicity of Steinernema scapterisci in monoxenic culture with different species of bacteria. Journal of Invertebrate Pathology, 62:289-294.

Frank, J.H., T.R. Fasulo, D.E. Short and A.S. Sweed. (2002). MCricket: Alternative Methods of Mole Cricket Control: A knowledgebase and tutorial on mole crickets and their control. (Version 2.0). UF/IFAS. SW-89.

McSorley, R., (July 1997). Soil-inhabiting nematodes. UF/IFAS Featured Creatures. EENY-12. http://creatures.ifas.ufl.edu/nematode/ soil_nematode.htm (August 1999).

Nguyen, K.B. (May 1999). Mole Cricket Control by Entomopathogenic Nematodes. UF/IFAS. http://kbn.ifas.ufl.edu/cricket/molecr.htm (June 1999).

Nguyen, K.B. (February 1999). Taxonomy of Entomopathogenic Nematodes. UF/IFAS. http://kbn.ifas.ufl.edu/kbnstein.htm (August 1999).
Nguyen, K.B. (February 1998). Symbiotic Bacteria of Entomopathogenic Nematodes. UF/IFAS. http://kbn.ifas.ufl.edu/biology/symbac.htm (August 1999).

Nguyen, K.B., and G.C. Smart, Jr. (1992). Life cycle of Steinernema scapterisci Nguyen and Smart, 1990. Journal of Nematology, 24:160-169.

Nguyen, K.B., and G.C. Smart, Jr. (1992). Addendum to the morphology of Steinernema scapterisci. Journal of Nematology, 24:478-481.

Nguyen, K.B., and G.C. Smart,Jr. (1991a). Pathogenicity of Steinernema scapterisci to selected invertebrates. Journal of Nematology, 23:7-11.

Nguyen, K.B., and G.C. Smart, Jr. (1991b). Mode of entry and sites of development of Steinernema scapterisci. Journal of Nematology, 23:267-268.

Nguyen, K.B., and G.C. Smart, Jr. (1990a). Preliminary studies on survival of Steinernema scapterisci in soil. Soil and Crop Science Society of Florida, Proceedings, 49:230-233.

Nguyen, K.B., and G.C. Smart, Jr. (1990b). Vertical dispersal of Steinernema scapterisci. Journal of Nematology, 22:574-578.

Nguyen, K.B., and G.C. Smart, Jr.(1990). Steinernema scapterisci n. sp. (Steinernematidae: Nematoda). Journal of Nematology, 22:187-199.

Parkman, J.P., J.H. Frank, K.. Nguyen, and G.C. Smart, Jr. (1994).Inoculative release of Steinernema scapterisci (Rhabditida: Steinernematidae) to suppress pest mole crickets (Orthoptera: Gryllotalpidae) of golf courses. Environmental Entomology, 23:1331-1337.

Parkman, J.P. J.H. Frank, K.B. Nguyen, and G. C. Smart, Jr. (1993).Dispersal of Steinernema scapterisci (Rhabditida: Steinernematidae) after inoculative applications for mole cricket (Orthoptera: Gryllotalpidae) control in pastures. Biological Control, 3:226-232.

Smart, Jr., G.C., and K.B. Nguyen (1995).Biological control of Orthoptera pest insects. 
United State Patent, patent number 5,466,448, date of patent: November, 141995.

Smart, G.C. Jr.,K.B. Nguyen, J.P. Parkman, and J.H. Frank (1990).Biological control of mole crickets in the genus Scapteriscus with the nematode Steinernema scapterisci Nguyen and Smart, 1990. Rencontres Caraibes en lutte biologique, Guadeloupe, 5-7 November 1990. Ed. INRA, Paris 1991. 